\title{
50. CRETACEOUS/TERTIARY BOUNDARY STUDIES AT DEEP SEA DRILLING PROJECT SITE 516, RIO GRANDE RISE, SOUTH ATLANTIC: A SYNTHESIS
}

\author{
N. Hamilton, Department of Geology, University of Southampton, \\ Southampton S09 5NH, United Kingdom
}

\begin{abstract}
At Site 516, Rio Grande Rise, southwestern Atlantic, a continuous depositional sequence is present across the Cretaceous/Tertiary boundary. This paper reviews the principal results of magnetostratigraphic, micropaleontologic, sedimentologic, and geochemical studies made across the boundary.
\end{abstract}

\section{INTRODUCTION}

A continuous depositional record across the Cretaceous/Tertiary (C-T) boundary is present at Site 516, located on the northern flank of the Rio Grande Rise (Fig. 1), drilled during DSDP Leg 72 . Site 516 lies in a water depth of $1313 \mathrm{~m}$ near the crest of the rise. Rotary drilling with continuous coring from 169 to $1251 \mathrm{~m}$ recovered a lower Miocene to Upper Cretaceous (Coniacian) sequence that is nearly stratigraphically complete and dominantly pelagic carbonate. We encountered the C-T boundary in Core 516F-89 at a sub-bottom depth of 964 $\mathrm{m}$. This synthesis chapter amalgamates the results of sedimentologic, paleontologic, paleomagnetic, and geochemical investigations undertaken on the "boundary core".

\section{BACKGROUND}

Renewed interest in C-T boundary studies stems primarily from the discovery by Alvarez and others (1979) of noble metal enrichment, particularly of iridium, in sediments at the C-T boundary in the Contessa section at Gubbio, Italy. Similar peaks in Ir abundance have since been reported from about a dozen other globally distributed localities, including the stratotype section of the C-T boundary at Stevns Klint in Denmark (Alvarez et al., 1981, and Michel et al., this volume). Such enrichments are found within a distinctive "boundary clay" layer in both marine and continental sections.

Alvarez and others (1980) propose that this anomalous enrichment relative to crustal abundances was caused by deposition of dust-size ejecta produced from an impacting asteroidal body, or bolide, of about $10 \mathrm{~km}$ in diameter. The mechanics of incorporation of high-velocity ejecta of $1-\mu \mathrm{m}$ size into the stratosphere for global redistribution are considered in detail by O'Keefe and Ahrens (1982). Independent evidence of a bolide impact comes from the reported discovery of sanidine spherules in the C-T boundary clay at Caravaca, Spain (Smit and Klaver, 1981). An alternative explanation for the noble metal enrichments proposed by Ruderman and Truran

\footnotetext{
${ }^{1}$ Barker, P. F., Carlson, R. L., Johnson, D. A., et al., Init. Repts. DSDP, 72: Washington (U.S. Govt. Printing Office).
}

(1980) involves transfer of Ir-rich lunar surface matter to the earth during intense emission of $\gamma$ rays accompanying a nearby supernova event.

A substantive case is emerging to relate the impact of the bolide to the major extinctions of biota occurring at the end of the Cretaceous (Alvarez et al., 1980; Ganapathy, 1980; Smit and Hertogen, 1980; Hsü, 1980). Others argue against the catastrophic event hypothesis in favor of gradual processes of biological change and evolutional turnover (see, for instance, Hickey, 1981; Archibald and Clemens, 1982; Mörner, 1982). These opposing interpretations both depend on the degree of stratigraphic resolution attainable in the fossil record and on the synchroneity or nonsynchroneity of selective extinctions.

Continued interdisciplinary investigation of newly discovered C-T boundary sequences is therefore essential. Recovery of intact C-T boundary sequences during the latest phase of drilling in the South Atlantic (Legs 7274) provides significant opportunities for such investigations. The combination of micropaleontologic biozonations with a precise magnetostratigraphy affords a reliable method of correlating these marine sequences to other global occurrences.

\section{CRETACEOUS/TERTIARY BOUNDARY AT SITE 516}

The interval in Core $516 \mathrm{~F}-89$ within which the C-T boundary occurs at Site 516 (see frontispiece to this volume) can be described lithologically as follows. Immediately below the biostratigraphically positioned boundary, the latest Maestrichtian sediment is a light gray to white bioturbated nannofossil limestone (516F-89-5, 35$43 \mathrm{~cm}$ ). Above this, and in sharp and irregular contact with it, is a thin dark clay layer $(516 \mathrm{~F}-89-5,34-34.5 \mathrm{~cm})$. Overlying the clay layer, there is a $3.5-\mathrm{cm}$ thick, light gray homogeneous limestone unit. Fine, darker-colored laminae penetrate downwards obliquely into the latter unit, and in the interval $516 \mathrm{~F}-89-5,28-30.5 \mathrm{~cm}$, a zone of these more clay-rich laminae occur (Michel et al., this volume). A reddish brown color dominates above the level of $516 \mathrm{~F}-89-5,29.5 \mathrm{~cm}$. This basal Paleocene sediment can be classified as a partially dolomitized microcrystalline limestone. 


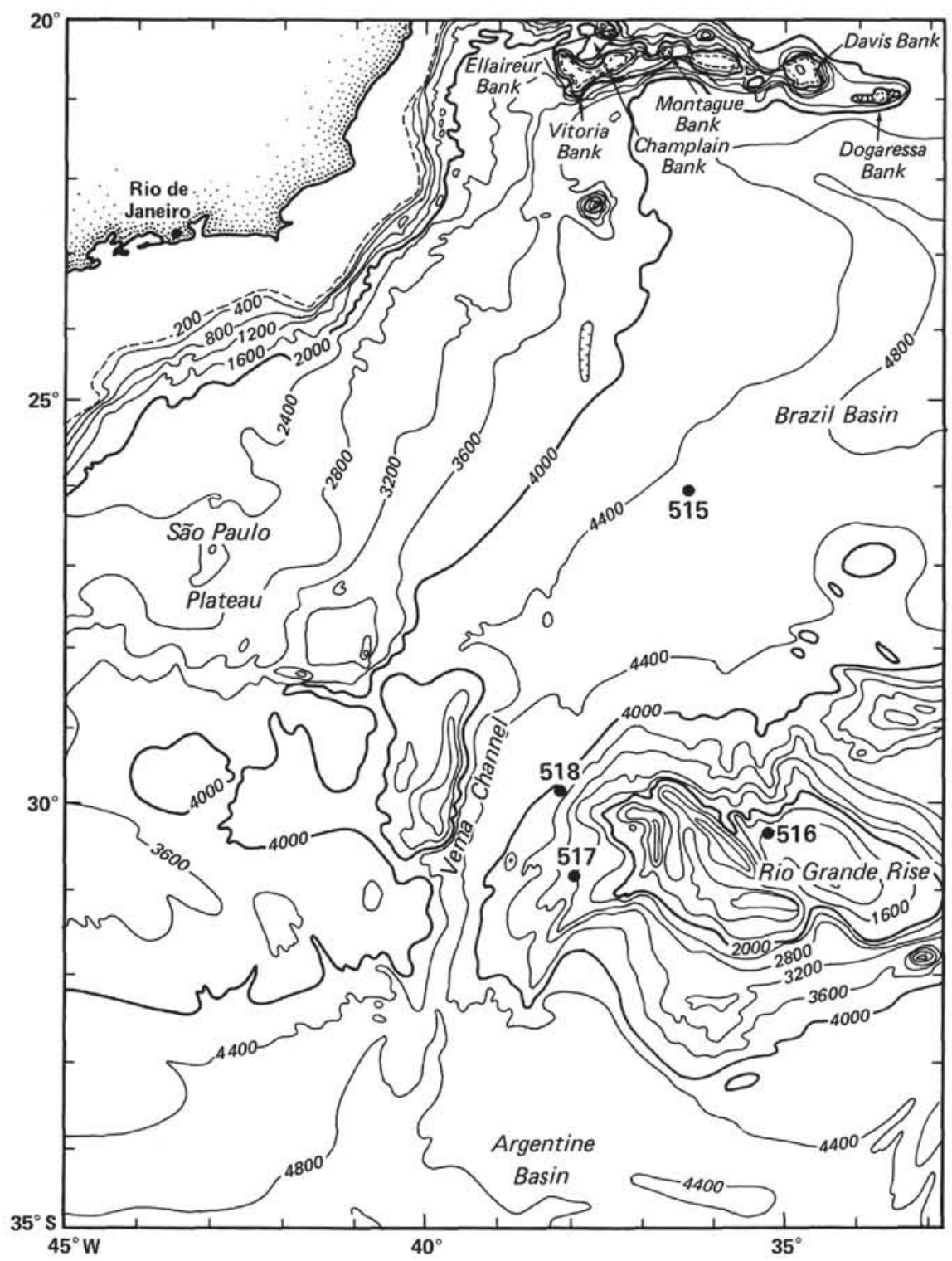

Figure 1. Location of Site 516 on Rio Grande Rise, South Atlantic.

Although it is debatable whether a true "boundary" clay exists at Site 516, the geochemical evidence (see Michel et al., this volume) does point to an important authigenic component in this clay layer and clay-rich laminae. These laminae are clearly different geochemically from other detrital clays found above and below the C-T boundary interval at this site.

Visual examination of the lithologies in the vicinity of the boundary do not reveal any indications of extensive mixing caused by bioturbation or the drilling process itself. Thus, the sedimentologic features observed near the boundary must record only the original depositional conditions and subsequent diagenetic modifications.

Calcareous nannoplankton zonation (site chapter, Site 516, this volume) shows that the first appearance datum of Biantholithus sparsus, a Paleocene indicator, occurs at $516 \mathrm{~F}-89-5,33.5 \mathrm{~cm}$, after the extinction of the late Maestrichtian zonal taxon Micula mura. Similarly, planktonic foraminiferal study (Pujol, this volume, and
Weiss, this volume) suggests that no major hiatus is present at the C-T boundary at Site 516. The top of the late Maestrichtian Abathomphalus mayaroensis Zone is recognized in Sample 516F-89-5, 29.3-31.2 cm, and the basal Paleogene subzone Pla occurs in the overlying interval 516F-89-5, 21-26 cm. Rare specimens of the subzonal standard species Globigerina eugubina are reported slightly lower in Sample 516F-89-5, 28-29.3 cm (Weiss, this volume). The basal Paleocene at Site 516 presents a poorly preserved, infrequent, and small-sized planktonic foraminiferal fauna. As in other occurrences, this is in marked contrast to the moderate preservation and relatively high abundance of the large-sized globotruncanids of the Upper Cretaceous at Site 516.

There is ample evidence from benthic foraminifers (Dailey, this volume) that major changes in faunal composition occur within the C-T boundary transition interval of the Rio Grande Rise. Dailey reports detailed population studies that reveal an accelerated rate of species' 
last appearances in the uppermost Maestrichtian. Some $30 \%$ of the Cretaceous benthic foraminiferal species become extinct. The earliest Paleocene is marked by a significant phase of new species introduction and fewer extinctions. Nevertheless, on the whole, the benthic foraminifers show a more gradual and moderate evolutionary turnover compared to the abrupt mass extinctions of the planktonic foraminiferal groups.

Figure 2 summarizes magnetobiostratigraphic and geochemical data from the C-T boundary core. Several features are worthy of comment. Direct correlation to the Contessa section at Gubbio, Italy (Alvarez et al., 1977 ) is possible from the polarity reversal record at Site 516 (Hamilton and Suzyumov, this volume). The C-T boundary occurs approximately $1.4 \mathrm{~m}$ below the base of the interval of normal polarity assigned to Anomaly 29 (Fig. 2). Relative to the magnetic record, this major chronostratigraphic boundary is now confirmed to occupy an identical position in sediment sequences from the southwestern Atlantic (this study), southeastern Atlantic (Poore et al., in press), Umbrian Apennines (Alvarez et al., 1977), Venetian Alps (Channell and Medizza, 1981), and the stratotype section at Stevns Klint, Denmark (Mörner, 1982).

An iridium-enriched region is detected over a $20.5-\mathrm{cm}$ interval in Section 516F-89-5 (Michel et al., this volume). A peak Ir abundance of 0.95 parts per billion $(\mathrm{ppm})$ is found at a level $(516 \mathrm{~F}-89-5,33-33.5 \mathrm{~cm})$ coinci- dent with the C-T boundary identification from calcareous nannoplankton (Fig. 2). Thus, there is evidence of an Ir anomaly at the C-T boundary preserved on the Rio Grande Rise. Stable isotopic (oxygen and carbon) study of the boundary core and adjacent Cores $516 \mathrm{~F}-88$ and $516 \mathrm{~F}-90$ (Williams et al., this volume) shows a most significant change in $\delta^{13} \mathrm{C}$ across the $\mathrm{C}$ - $\mathrm{T}$ boundary. There is a sharp decrease, a $1.8 \%$ depletion, from the late Maestrichtian into the early Danian, followed by a slow increase. $\delta^{18} \mathrm{O}$ values show more variability, but interpretation of isotopic paleotemperatures suggests cooling just below the C-T boundary and a subsequent temperature increase across the boundary. Williams and others (this volume) demonstrate some notable lead-lag relationships between $\delta^{18} \mathrm{O}, \delta^{13} \mathrm{C}$, and total $\mathrm{CaCO}_{3}$.

\section{CONCLUSIONS}

The continuous recovery of a sequence of Paleocene and Late Cretaceous pelagic carbonates at Site 516 on the Rio Grande Rise provides a useful stratotype reference section for the southwestern Atlantic. Magnetobiostratigraphic study proves that the C-T boundary is preserved in this sequence. As in many other localities, these marine sediments spanning the boundary contain evidence of major extinctions of planktonic and benthic foraminifers and nannofossils that reflect important, and possibly dramatic, environmental changes in the oceans some $65 \mathrm{Ma}$. Evidence of a definite Ir anomaly is
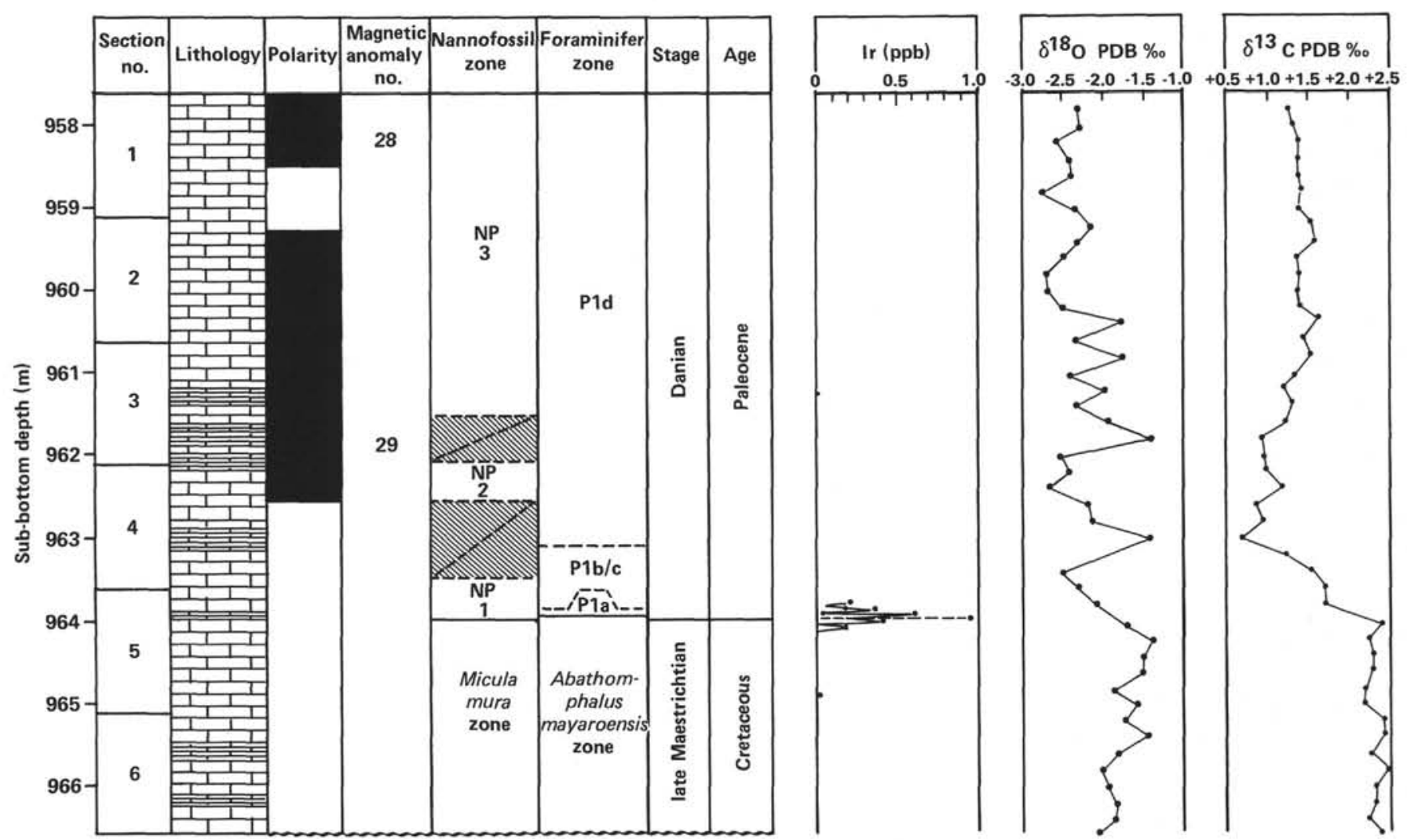

Figure 2. Cretaceous/Tertiary boundary Core $516 \mathrm{~F}-89$, magnetobiostratigraphy and geochemical data. Data sources (this volume): magnetic polarities (Hamilton and Suzyumov); calcareous nannoplankton zonation (site chapter, Site 516, this volume); foraminiferal zonation (Pujol, Weiss); iridium abundances (Michel et al.); stable carbon and oxygen isotopes (Williams et al.). Note: iridium data point error bars omitted for clarity; see detailed plot in Michel et al. (Figure 2). 
also found, together with marked fluctuations in the oxygen and carbon isotopic record. These integrated studies provide for the first time for a southwestern Atlantic drilling site new data pertinent to the growing debate about the true nature of the terminal Cretaceous events.

\section{REFERENCES}

Alvarez, L. W., Alvarez, W., Asaro, F., and Michel, H. V., 1980. Extraterrestrial cause for the Cretaceous-Tertiary extinction. Science 208:1095-1108.

Alvarez, W., Alvarez, L. W., Asaro, F., and Michel, H. V. 1979. Anomalous iridium levels at the Cretaceous-Tertiary boundary at Gubbio, Italy. Negative results of tests for a supernova origin, Proc. Cretaceous-Tertiary Boundary Events Symp., 2:69.

Alvarez, W., Arthur, M. A., Fischer, A. G., Lowrie, W., Napoleone, G., Premoli Silva, I., and Roggenthen, W. M., 1977. Upper Cretaceous-Paleocene magnetic stratigraphy at Gubbio, Italy-V-type section for the Late Cretaceous-Paleocene geomagnetic reversal time scale. Geol. Soc. Am. Bull., 88:383-389.

Alvarez, W., Asaro, F., Alvarez, L. W., and Aichel, H. V., 1981. Current Status of the Impact Theory for the Terminal Cretaceous Extinction: Boulder, CO (Geol. Soc. Am. Spec. Publ.).

Archibald, J. D., and Clemens, W. A., 1982. Late Cretaceous extinctions. Am. Sci. 70:377-385.

Channell, J. E. T., and Medizza, F., 1981. Upper Cretaceous and Palaeogene magnetic stratigraphy and biostratigraphy from the Venetian (southern) Alps. Earth Planet. Sci. Lett., 55:419-432.
Ganapathy, R., 1980. A major meteorite impact on the Earth 65 million years ago. Evidence from the Cretaceous-Tertiary boundary clay. Science, 209:921-923.

Hickey, L. J., 1981. Land plant evidence compatible with gradual, not catastrophic, change at the end of the Cretaceous. Nature, 292: 529-531.

Hsü, K. J., 1980. Terrestrial catastrophe caused by cometary impact at the end of Cretaceous. Nature, 285:201-203.

Mörner, N. A., 1982. The Cretaceous boundary: chronostratigraphic position and sequence of events. J. Geol, 90:564-573.

O'Keefe, J. D., and Ahrens, T. J., 1982. Impact mechanics of the Cretaceous-Tertiary extinction bolide. Nature, 298:123-127.

Poore, R. Z., Tauxe, L., Percival, S. F., Jr., LaBrecque, J. L., Wright, R., Petersen, N. P., Smith, C. C., Tucker, P., and Hsü, K. J., in press. Late Cretaceous-Cenozoic magnetostratigraphy and biostratigraphic correlations of the South Atlantic Ocean: DSDP Leg 73. In Hsü, K. J., LaBrecque, J. L., et al., Init. Repts. DSDP, 73: Washington (U.S. Govt. Printing Office).

Ruderman, M., and Truran, J. W., 1980. Possible transfer of lunar matter to Earth due to a nearby supernova. Nature, 284:328-329.

Smit, J., and Hertogen, J., 1980. An extraterrestrial event at the Cretaceous-Tertiary boundary. Nature, 285:198-200.

Smit, J., and Klaver, G., 1981. Sanidine spherules at the CretaceousTertiary boundary indicate a large impact event. Nature, 292:47-49.

Date of Initial Receipt: October 28, 1982 